\title{
Hydrogen sulfide is involved in the chilling stress response in Vitis vinifera $\mathrm{L}$.
}

\author{
Peining Fu, Wenjie Wang, Lixia Hou, Xin Liu* \\ Key Laboratory of Plant Biotechnology in Universities of Shandong Province/College of Life Science, Qingdao Agricultural University, Changcheng Road 700, Chengyang District, Qingdao City, Shandong \\ Province 266109, China
}

\section{Abstract}

Hydrogen sulfide $\left(\mathrm{H}_{2} \mathrm{~S}\right)$ is an important signaling molecule involved in several stress-resistance processes in plants, such as drought and heavy metal stresses. However, little is known about the roles of $\mathrm{H}_{2} \mathrm{~S}$ in responses to chilling stress. In this paper, we demonstrated that chilling stress enhance the $\mathrm{H}_{2} \mathrm{~S}$ levels, the $\mathrm{H}_{2} \mathrm{~S}$ synthetase (L-/D-cysteine desulfhydrase, L/DCD) activities, and the expression of L/DCD gene in Vitis vinifera L. 'F-242'. Furthermore, the seedlings were treated with sodium hydrosulfide (NaHS, a $\mathrm{H}_{2} \mathrm{~S}$ donor) and hypotaurine ( $\mathrm{HT}$, a $\mathrm{H}_{2} \mathrm{~S}$ scavenger) at $4^{\circ} \mathrm{C}$ to examine the effects of exogenous $\mathrm{H}_{2} \mathrm{~S}$ on grape. The results revealed that the high activity of superoxide dismutase and enhanced expression of $V v I C E 1$ and $V v C B F 3$ genes, but low level of superoxide anion radical, malondialdehyde content and cell membrane permeability were detected after addition of NaHS. In contrast, HT treatment displayed contrary effect under the chilling temperature. Taken together, these data suggested that $\mathrm{H}_{2} \mathrm{~S}$ might be directly involved in the cold signal transduction pathway of grape.

Keywords: hydrogen sulfide, chilling stress, Vitis vinifera L.

\section{Introduction}

Hydrogen sulfide $\left(\mathrm{H}_{2} \mathrm{~S}\right)$ is a novel gasotransmitter along with nitric oxide (NO) and carbon monoxide (CO) [1]. Many data indicate that most of the endogenously synthesized $\mathrm{H}_{2} \mathrm{~S}$ occurred via L-cysteine desulfhydrase (LCD, EC4.4.1.1) and D-cysteine desulfhydrase (DCD, EC4.4.1.15) in high plants [2-5]. Recent studies show that $\mathrm{H}_{2} \mathrm{~S}$ is involved not only in plant responses to drought and copper stresses but also in tolerance to salinity, heat, cadmium, boron and chromium stresses [6-10]. It is reported that exogenous $\mathrm{H}_{2} \mathrm{~S}$ can enhance the resistance of plants to drought stress [11-14] and copper stress [15,16] by improving the activities of antioxidant enzymes, such as superoxide dismutase (SOD), catalase (CAT), and peroxidase (POD). However, whether endogenous $\mathrm{H}_{2} \mathrm{~S}$ is involved in plant cold stress response is poorly known.

Signal molecules are involved in perception and transduction of low temperature signal and mediate chilling adaptive responses through physiological processes and transcription factors [17-20]. Recent research indicated that multiple transcription factors and inducers, such as C-repeat-binding factor (CBF), inducers of CBF expression (ICE) and cold-regulated (COR)

* Corresponding author. Email: liuxin6080@126.com

Handling Editor: Grażyna Kłobus

This is an Open Access digital version of the article distributed under the terms of the Creative Commons Attribution 3.0 License

(creativecommons.org/licenses/by/3.0/), which permits redistribution, commercial and non-commercial, provided that the article is properly cited.

(c) The Author(s) 2013 Published by Polish Botanical Society genes, played pivotal roles in the resistance to low temperature stress [21-23]. Many signal molecules can improve plant tolerance to low temperature stress by altering the expression levels of $C O R, C B F s$ and ICE1 genes. For example, ethylene molecules negatively regulate cold tolerance by repressing expression of CBFs [25]. Inositol 1, 4, 5-trisphosphate (IP3) and $\mathrm{Ca}^{2+}$ induce $C B F s$ and COR expression in plant [25]. NO positively regulate the expression of cold related genes COR15a, LT130 and LTI78 in Arabidopsis under low temperature conditions [17]. However, whether $\mathrm{H}_{2} \mathrm{~S}$ regulates expression of these cold related genes in the response of chilling adaptive is still poorly understood.

Different species of grape exhibit varying level of resistance to cold hardiness, ranging from the cold susceptive grape ('Maoputao', Vitis quinqanguoari Rehd. cv. Maoputao) to the high resistant grape 'Zuoshan1' (Vitis amurensis Rupr. cv. Zuoshan1) [26]. Even though the many researches about low temperature have been conducted in grape [26], the mechanism of low temperature resistance in grape at molecular level as well as the signal transduction pathways reminds unclear. In this paper, exogenous $\mathrm{H}_{2} \mathrm{~S}$ was studied in cold-tolerant grapevine 'F-242' in response of cold stress. Our results showed that $\mathrm{H}_{2} \mathrm{~S}$ was involved in cold stress response in grape by regulating superoxide anion radical content, MDA content, the relative permeability of cell membrane and SOD activity, as well as expression of $V v I C E 1$ and $V v C B F 3$.

\section{Material and methods}

\section{Plant materials, growth conditions, and treatments}

Vitis vinifera L. 'F-242' (tissue culture seedling), a cold resistant variety in Shandong province of China, was maintained 
in $1 / 2 \mathrm{MS}$ medium, under a $16 \mathrm{~h}$ light $/ 8 \mathrm{~h}$ dark photoperiod at $25^{\circ} \mathrm{C}$. Four-weeks old seedlings were exposed to $4^{\circ} \mathrm{C}$ and $25^{\circ} \mathrm{C}$ for $0,1,3,5,7,9,11$ and $22 \mathrm{~h}$, respectively. Fully expanded leaves were harvested to determine cell membrane permeability, content of $\mathrm{H}_{2} \mathrm{~S}, \mathrm{MDA}$ and superoxide anion radical, activities of L-/D-cysteine desulfhydrase and SOD, and the expression levels of $V v L C D$ and $V v D C D$ genes.

Meanwhile, the plantlets were treated with $0.1 \mathrm{mM} \mathrm{HT}$ and $\mathrm{NaHS}$ (distilled water as a control) for $1 \mathrm{~h}$, and then measured the cell membrane permeability, MDA content, superoxide anion radical content and SOD activities at their burst time under $4^{\circ} \mathrm{C}$ and $25^{\circ} \mathrm{C}$. In addition, the seedlings treated (spraying) with the same concentration of $\mathrm{HT}$ and $\mathrm{NaHS}$ were exposed to $4^{\circ} \mathrm{C}$ for $7 \mathrm{~h}$ and $3 \mathrm{~d}$. After that, leaves were harvested and immediately frozen in liquid nitrogen for RNA extraction. The expression levels of $V v I C E 1$ and $V v C B F 3$ genes were determined by quantitative RT-PCR.

\section{Measurement of $\mathrm{H}_{2} \mathrm{~S}$ content}

Measurement of $\mathrm{H}_{2} \mathrm{~S}$ content was performed as described by by Liu et al. [27].

\section{L-/D-cysteine desulfhydrase activity measurements}

L-/D-cysteine desulfhydrase activity measurements were performed as described by Liu et al. [27].

\section{Superoxide anion radical content measurement}

Measurement of superoxide anion radical content was conducted referring to Zhao and Zhou [28] with some modifications. $0.5 \mathrm{~g}$ leaves was homogenized with $5 \mathrm{ml} 50 \mathrm{mM}$ potassium phosphate buffer at $4^{\circ} \mathrm{C}$ and centrifuged at $10000 \mathrm{rpm}$ for 10 min. Mixed $0.5 \mathrm{ml} 50 \mathrm{mM}$ potassium phosphate buffer $1 \mathrm{ml} 1$ $\mathrm{mM}$ hydroxylamine hydrochloride (Sigma, USA) and $0.5 \mathrm{ml}$ crude extract in reaction tubes, incubated at $25^{\circ} \mathrm{C}$ for $1 \mathrm{~h}$, then added $1 \mathrm{ml}$ of $17 \mathrm{mmol}^{-1}$ sulfanilic acid and $1 \mathrm{ml}$ of $7 \mathrm{mmol}^{-1}$ a-naphthylamine (Sigma, USA) in reaction tubes, incubated at $25^{\circ} \mathrm{C}$ for $20 \mathrm{~min}$, and the absorbance was read at $530 \mathrm{~nm}$. Converted the photometric value to nitrite content via standard curve of nitrite and hydroxylamine reaction, and the content equaled to half of nitrite was measured.

\section{MDA content measurement}

Lipid peroxidation was estimated by concentration of thiobarbituric acid reactive substances (TBARS) [29]. First, $0.1 \mathrm{~g}$ leaves was homogenized with $1 \mathrm{ml} \mathrm{10 \% (w/v)} \mathrm{trichloroacetic}$ acid (TCA; Sigma, USA) and the homogenate was centrifuged at $12000 \mathrm{rpm}$ for $10 \mathrm{~min}$. Then $500 \mu \mathrm{l}$ of the supernatant was mixed with $500 \mu 10 \%(\mathrm{w} / \mathrm{v})$ TCA containing $0.6 \%(\mathrm{w} / \mathrm{v})$ thiobarbituric acid (TBA; Sigma, USA). The mixture was incubated in boiling water for $15 \mathrm{~min}$, cooled to room temperature, and centrifuged at $12000 \mathrm{rpm}$ for $10 \mathrm{~min}$. Absorbance of the supernatant was measured at $532 \mathrm{~nm}$, and the non-specific absorbance was measured at $600 \mathrm{~nm}$. The MDA content was determined using a molar extinction coefficient of $155 \mathrm{mM}^{-1} \mathrm{~cm}^{-1}$ [30].

\section{Membrane permeability measurement}

Harvested leaves were washed with deionized water and slightly dried with filter paper. Leaf-disc was taken by punching bear, and then incubated in deionized water at $25^{\circ} \mathrm{C}$ for $1 \mathrm{~h}$. Electrical conductivity (EC1) of the extravasation solution was measured using a conductivity meter (YSI model 55). Total ionic strength was determined after heating the solution in a $100^{\circ} \mathrm{C}$ water bath for $10 \mathrm{~min}$, and the electrical conductivity (EC2) was measured after cooling the solution to $25^{\circ} \mathrm{C}$ as described by Welti et al. [31]. Membrane relative permeability was calculated by the formula $E C 1 / E C 2 \times 100 \%$.

\section{SOD activity measurement}

Measurement of SOD activity was performed as described by Donahue et al. [32]. First, $0.5 \mathrm{~g}$ leaves was homogenized with $5 \mathrm{ml} 50 \mathrm{mM}$ potassium phosphate buffer at $4^{\circ} \mathrm{C}$ and centrifuged at $10000 \mathrm{rpm}$ for $10 \mathrm{~min} .200 \mu \mathrm{l}$ crude extract was mixed with 3 $\mathrm{ml} 50 \mathrm{mM}$ potassium phosphate buffer in reaction tubes and then illuminated (fluorescent light, $40 \mathrm{~W}$ ) for $20 \mathrm{~min}$. The absorbance was measured at $560 \mathrm{~nm}$, taken the reaction solution without illumination as a control. A calibration curve with commercial SOD (Sigma, USA) was utilized to calculate SOD activity. One unit of SOD was defined as the amount of enzyme required to cause a $50 \%$ reduction of nitrotetrazolium blue chloride.

\section{Quantitative RT-PCR}

Total RNA of grape leaves was extracted with CTAB method as presented by Iandolino et al [33]. First-strand cDNA was synthesized from $4 \mathrm{ng}$ DNase I (TaKaRa, Japan) -treated total RNA using M-MLV reverse transcription kit (TaKaRa, Japan). Quantitative RT-PCR was performed using MyiQ real-time PCR detection system (Bio-Rad, USA) with the presence of SYBR Green I (BioWhittaker Molecular Applications) in the amplification mixture according to the manufacturer's protocols. Specific primer pairs were designed for $V v L C D$ (forward primer 5'-CACTACGCAAACGGAGCACA-3', reverse primer 5'-TCATTATTCACCGCCATCACC-3'), $V v D C D$ (forward primer 5'-CGATAGGAGGCATCCAAAGC-3', reverse primer 5'-TCCAATTAAACGTTCAACCAAGA-3'), VvICE1 (forward primer 5'- GGTGGAAGTAACTCAAATGC-3', reverse primer 5'- GCTCCTTCAAGTACTCAATAGC-3'), $V v C B F 3$ (forward primer 5'- CAATAGATGGGTATGCGAAGTG -3', reverse primer 5'-CTGTATGTCCCTAGCTGAAGATGAC-3') and $V v A C T I N$ (forward primer 5'-TACGAGCAAGAGCTGGAAA-3', reverse primer 5'-AATGAGAGATGGCTGGAAGAG-3). Amplification of actin transcripts served as the internal standard. The data were analyzed using MyiQ software (Bio-Rad).

\section{Data processing and statistical analysis}

The DPS data processing system was used to carry out the significance analysis of the data. $P$ value $<0.05$ was considered statistically significant.

\section{Results}

\section{Chilling treatment increased endogenous $\mathrm{H}_{2} \mathrm{~S}$ level and activity of L-/D-cysteine desulfhydrase in grape leaves}

Endogenous $\mathrm{H}_{2} \mathrm{~S}$ content and the activity of VvLCD and VvDCD were detected in grape leaves in order to investigate $\mathrm{H}_{2} \mathrm{~S}$ function in response to chilling temperature. When the grape seedlings were exposed to $4^{\circ} \mathrm{C}, \mathrm{H}_{2} \mathrm{~S}$ content did not change within the first three hours of cold treatment, but increased and reached the peak $5 \mathrm{~h}$ after the start of cold treatment, then deceased sharply to the normal level $(P<0.05$; Fig. 1a). Additionally, the activity of VvL/DCD was measured at the same treatment condition to determine if the enzyme was involved in $\mathrm{H}_{2} \mathrm{~S}$ accumulation. Similarly to the accumulation pattern of $\mathrm{H}_{2} \mathrm{~S}$, the activity of VvLCD and VvDCD were enhanced and 

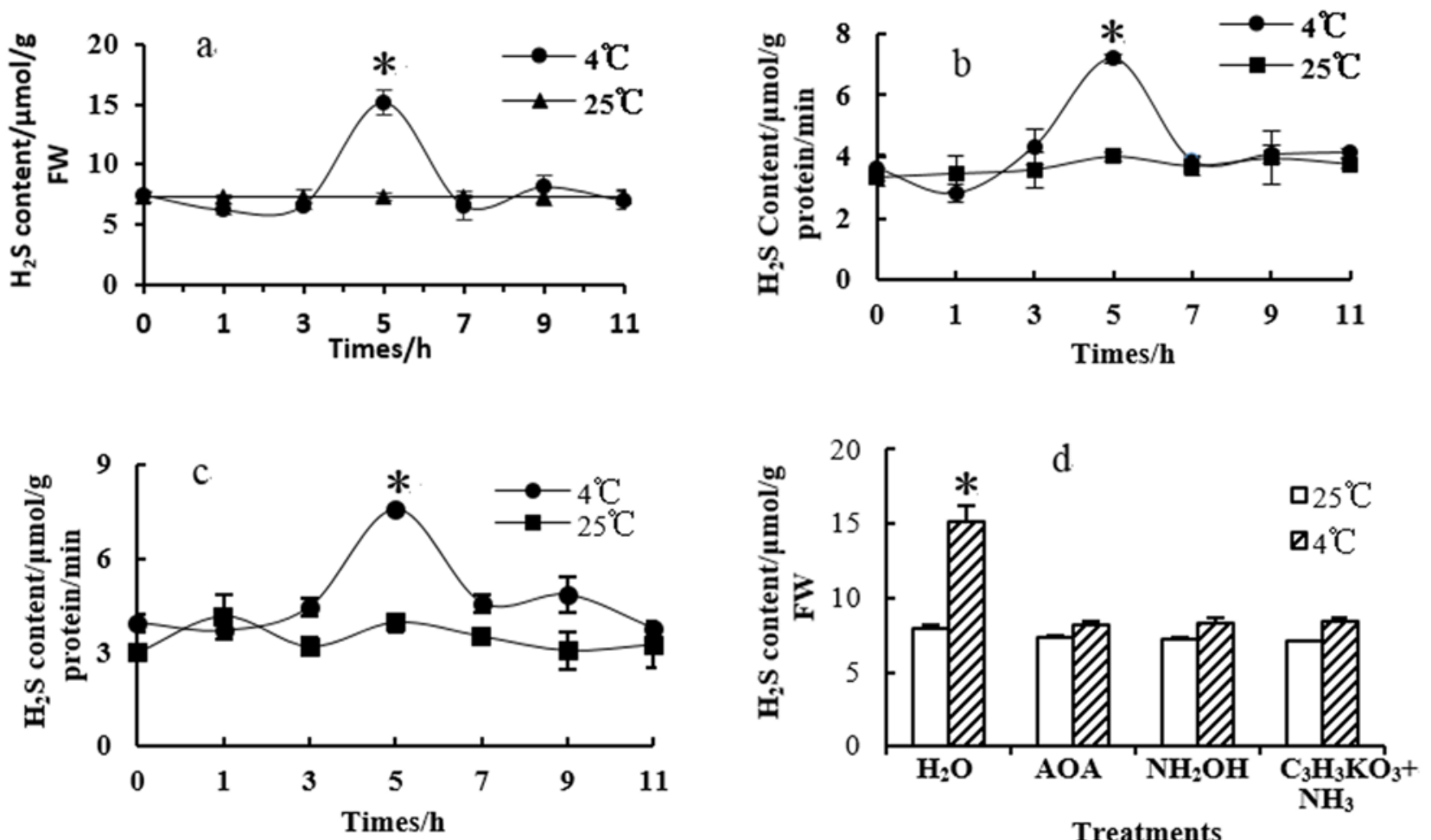

Fig. 1 Detection of endogenous $\mathrm{H}_{2} \mathrm{~S}$ contentand L/DCD activity in 'F-242' leaves under chilling stress. The values represent the average of three independent samples. a Effects of chilling on $\mathrm{H}_{2} \mathrm{~S}$ content. $\mathbf{b}$ Effects of chilling on LCD activity. $\mathbf{c}$ Effects of chilling on DCD activity. d Effects of $\mathrm{H}_{2} \mathrm{~S}$ synthesis inhibitors ( $\mathrm{AOA}, \mathrm{NH}_{2} \mathrm{OH}$ and $\mathrm{C}_{3} \mathrm{H}_{3} \mathrm{KO}_{3}+\mathrm{NH}_{3}$ ) on chilling-induced $\mathrm{H}_{2} \mathrm{~S}$ content. Error bars indicate $\pm S E$. ${ }^{*}$ indicates significant differences at $P<0.05$ (Student's $t$-test).

reached a peak $5 \mathrm{~h}$ after the start of $4^{\circ} \mathrm{C}$ treatment $(P<0.05)$ (Fig. 1b,c). Furthermore, $\mathrm{H}_{2} \mathrm{~S}$ accumulation was inhibited by L-/D-cysteine desulfhydrase production [aminooxy acetic acid (AOA), $\mathrm{NH}_{2} \mathrm{OH}$ or potassium pyruvate $\left(\mathrm{C}_{3} \mathrm{H}_{3} \mathrm{KO}_{3}\right)+$ $\mathrm{NH}_{3} ; P<0.05$; Fig. 1d]. These results indicated that chilling temperature induce the $\mathrm{H}_{2} \mathrm{~S}$ accumulation probably by L-/Dcysteine desulfhydrase.

\section{Expression of $\mathrm{L} / \mathrm{DCD}$ genes was induced by cold stress in grape leaves}

Primers for $V v L C D$ (forward primer 5'-TCTAGAATGGCTTCCAGACTCCTCC-3', reverse primer 5'-GGTACCTTAATGCAACATTTCATCTCTGTGT-3') and $V v D C D$ (forward primer 5'-GTCGACATGGAGGCAACCAAGCAACT-3', reverse primer 5'-GGTACCTTAGTAGAACATTTTTCCAATACCATC-3') genes were designed based on the mRNA sequence of Vitis vinifera L. PN40024 (accession number: XM_003635001 and XM_002263322) and the targeted genes were cloned in grape 'F-242'. In contrast with PN40024, VvLCD showed some differences in nucleotide sequences $\left(27^{\mathrm{C}-\mathrm{T}}, 666^{\mathrm{T}-\mathrm{G}}, 943^{\mathrm{C}-\mathrm{A}}, 1038^{\mathrm{G}-}\right.$ ${ }^{\mathrm{T}}, 1143^{\mathrm{G}-\mathrm{A}}$; Fig. 2a) but amino acid sequences was conserved (Fig. 2b). Meanwhile, $V v D C D$ presented some changes in nucleotide sequences $\left(42^{\mathrm{G}-\mathrm{A}}, 156^{\mathrm{C}-\mathrm{T}}, 456^{\mathrm{A}-\mathrm{G}}, 537^{\mathrm{A}-\mathrm{G}}, 734^{\mathrm{T}-\mathrm{A}}, 907^{\mathrm{G}-}\right.$ A, $1059^{\mathrm{A}-\mathrm{G}}, 1067^{\mathrm{G}-\mathrm{A}}, 1088^{\mathrm{G}-\mathrm{A}}, 1096^{\mathrm{A}-\mathrm{G}}, 1113^{\mathrm{C}-\mathrm{A}}, 1120^{\mathrm{A}-\mathrm{G}}$; Fig. 3a) and amino acid sequences $\left(245^{\mathrm{L}-\mathrm{H}}, 303^{\mathrm{V}-\mathrm{I}}, 356^{\mathrm{G}-\mathrm{E}}, 363^{\mathrm{C}-\mathrm{Y}}, 366^{\mathrm{N}-\mathrm{D}}\right.$, $374^{\mathrm{K}-\mathrm{E}}$; Fig. $3 \mathrm{~b}$ ). In addition, $V v L C D$ and $V v D C D$ were submitted to NCBI, and accession numbers are KC505216 and KC505217.

Furthermore, expression level of $V v L C D$ and $V v D C D$ were analyzed by quantitative RT-PCR. Expression pattern were similar between $V v L C D$ and $V v D C D$, which reached their peak at $3 \mathrm{~h}$ and $5 \mathrm{~h}$, respectively, then gradually declined to almost normal expression levels at $11 \mathrm{~h}$ cold treatment (Fig. 4). These results were in good agreement the profiles of $\mathrm{H}_{2} \mathrm{~S}$ accumulation and corresponding $\mathrm{H}_{2} \mathrm{~S}$ synthetase activity (Fig. 1). In conclusion, there is a hypothesis that $\mathrm{H}_{2} \mathrm{~S}$ is involved in the chilling signaling pathway of grapevine 'F-242'.

Effects of NaHS and HT on the levels of superoxide anion radical, MDA, the relative permeability of cell membrane and SOD activity in grape leaves

Superoxide anion radical content, MDA levels, the relative permeability of cell membrane and SOD activity were identified in grape seedlings treated with $\mathrm{NaHS}$ and HT. The data revealed that the superoxide anion radical content (Fig. 5a), MDA content (Fig. 5b), the relative permeability of cell membrane (Fig. 5c) and SOD activity (Fig. 5d) were all significantly increased at $3 \mathrm{~h}, 5 \mathrm{~h}, 11 \mathrm{~h}$ and $3 \mathrm{~h}$, respectively, in the grape leaves after $4^{\circ} \mathrm{C}$ treatment. While a decline occurred for superoxide anion radical, MDA and the relative permeability of the plasma membrane in the seedlings pretreated with NaHS (Fig. 5e-g). As was expected, the seedlings pretreated with HT presented the contrary results (Fig. 5e-g). However, SOD activity showed opposite changes, with the increase of SOD by NaHS addition and decreased by HT pretreatment (Fig. 5h).

Thus, it was suggested that $\mathrm{H}_{2} \mathrm{~S}$ could reduce the level of superoxide anion radical and MDA, and improve SOD activity and the plasma membrane stability of grape leaves under low temperature condition.

\section{Effects of NaHS and HT on transcription levels of VvICE1 and VvCBF3}

To explore the possible targets of $\mathrm{H}_{2} \mathrm{~S}$ during chilling acclimation, transcription levels of cold-responsive genes VvICE1 and $V v C B F 3$ were analyzed in $4^{\circ} \mathrm{C}$ acclimated ' $\mathrm{F}-242$ ' seedlings that were pretreated with $\mathrm{NaHS}$ and HT. At normal temperature 


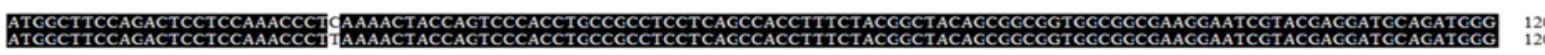

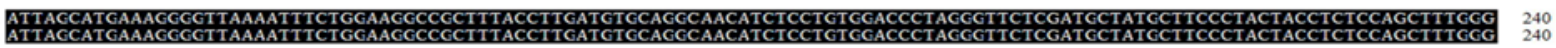

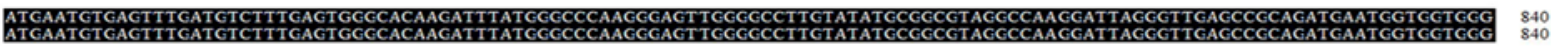

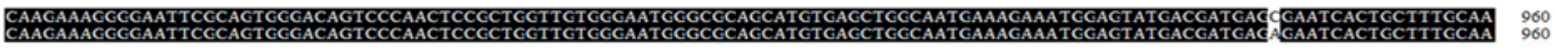

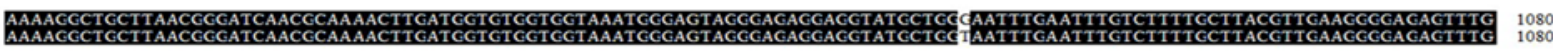

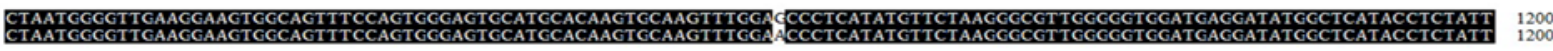

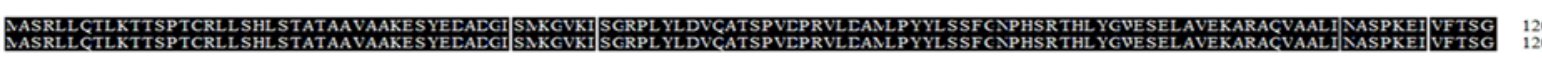

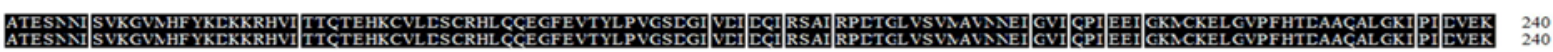

Fig. 2 Nucleotide (a) and amino acid (b) differences of VvLCD between 'PN40024' and 'F-242'.

a

${ }_{\mathrm{F}, 242.24}$

F -242

${ }_{\mathrm{P} F-242}^{\mathrm{P} 44024}$

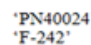

'pN40024

${ }^{-}-242^{2}$

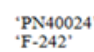

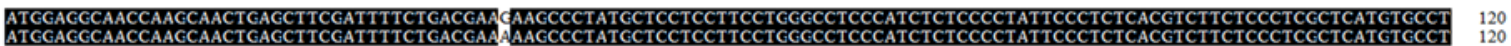

ACTCCIATTCATAACTCEAATCTTCCIAATTTACG CAAAAACACTCAACTCTCEATTAACCCTCATCACCTTTCTCEAATCCAAATCACTCGTAACAAACTCACAAAACTCCAATTCTTG 24

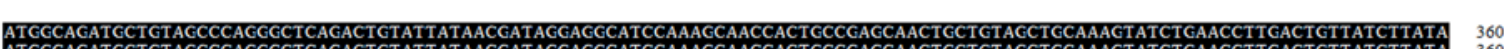

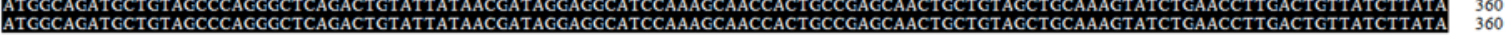

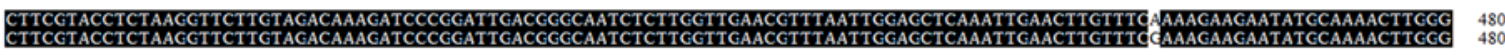

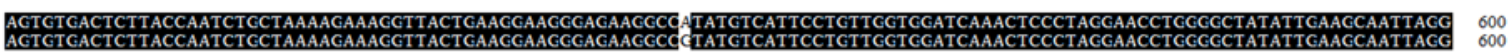

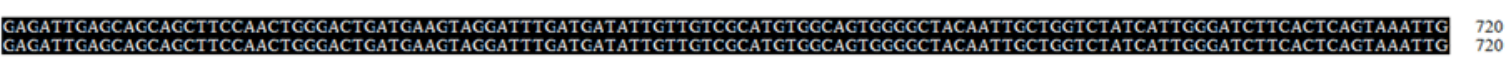

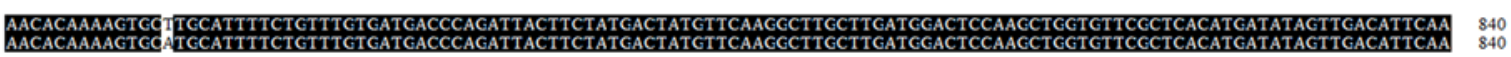

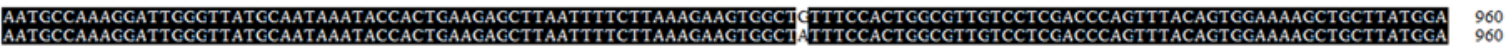

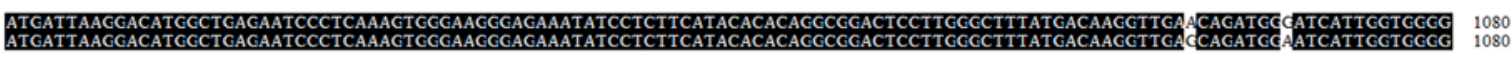

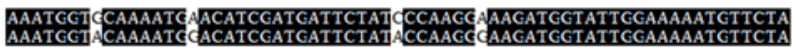

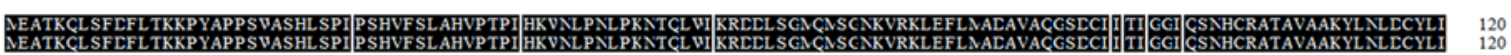

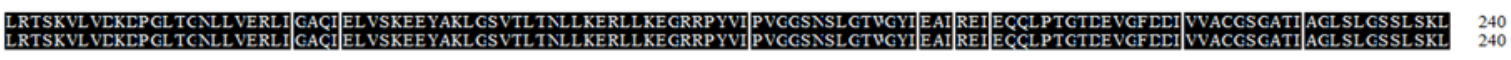

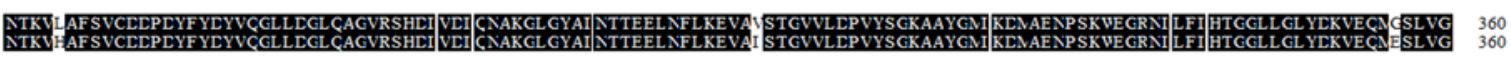

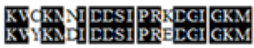

Fig. 3 Nucleotide (a) and amino acid (b) differences of VvDCD between 'PN40024' and 'F-242'. 


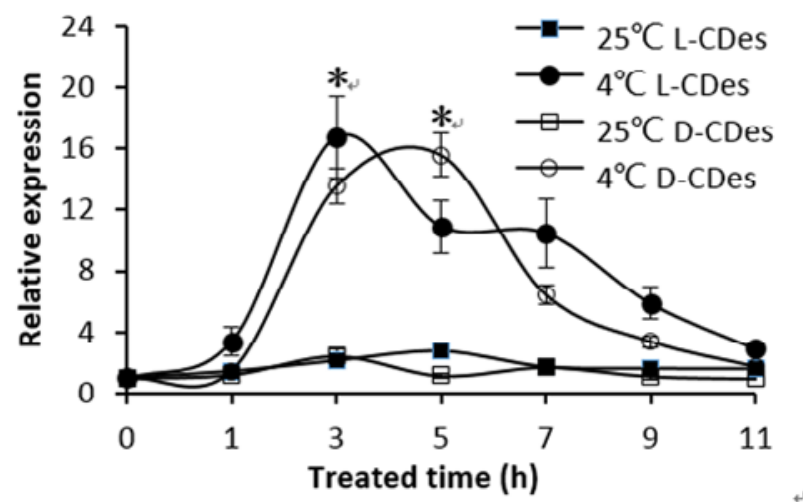

Fig. 4 Expression patterns of $V v L C D$ and $V v D C D$ in 'F-242' under chilling stress. The relative expression of $V v L C D$ and $V v D C D$ was quantified in comparison with the $V v A C T I N$ using quantitative RT-PCR with gene-specific primers (see "Material and methods"). The values represent the average of three independent samples. Error bars indicate $\pm S E$. ${ }^{*}$ indicates significant differences at $P<0.05$ (Student's $t$-test).

$\left(25^{\circ} \mathrm{C}\right)$, expression of $V v I C E 1$ and $V v C B F 3$ in 'F-242' were at low levels whether NaHS and HT were applied or not (Fig. 6). However, cold treatment significantly enhanced expression levels of $V v I C E 1$ and $V v C B F 3$, which were further induced by the application of NaHS, but suppressed by HT (Fig. 6). Thus, there is a hypothesis that $\mathrm{H}_{2} \mathrm{~S}$ play an important role in grape responses to cold stress by modulating VvICE1 and $V v C B F 3$ expression.
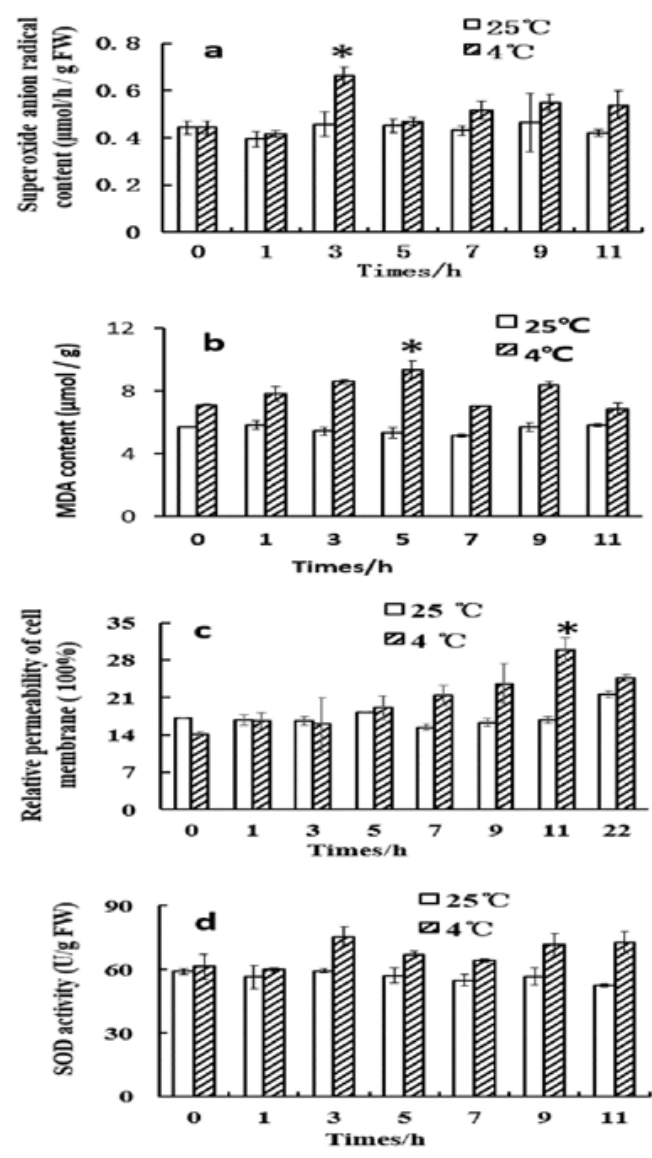

\section{Discussion}

Recent studies in plants revealed that $\mathrm{H}_{2} \mathrm{~S}$ plays multiple roles in the modulation of various physiological processes [3], such as copper, cadmium, drought, salinity and heat et al. [6-10]. In addition, our results indicate that the content of $\mathrm{H}_{2} \mathrm{~S}$ was rapidly increased by low temperature. All the results reveal that $\mathrm{H}_{2} \mathrm{~S}$ may be an important signaling molecule in plant responses to abiotic stresses.

In mammals, $\mathrm{H}_{2} \mathrm{~S}$ is produced from L-cysteine by at least four separate pathways, such as cystathionine $\beta$ synthetase (CBS, EC 4.2.1.22), cystathionine $\gamma$ lyase (CSE, EC 4.4.1.1), cysteine aminotransferase (CAT, EC 2.6.1.3) and cysteine lyase (CL, EC 4.4.1.10) [34], and CBS and CSE consistently demonstrated to produce $\mathrm{H}_{2} \mathrm{~S}$ in mammalian tissues [1,35]. Similar to animals, the homologs of CBS (LCD) and CSE (DCD) also are found in plants, and they are reported mainly responsible for generating $\mathrm{H}_{2} \mathrm{~S}[4,36]$. LCD (At3g62130) and DCD (At1g48420) genes have been isolated from Arabidopsis [2,37]. Meanwhile, the homolog genes of CDes also were isolated from $B$. napus and O. sativa [38]. In our study, we isolated $L C D$ and $D C D$ genes from 'F-242'. Moreover, we also find the transcription levels and enzyme activities of LCD and DCD were induced by $4^{\circ} \mathrm{C}$ acclimation. However, inhibitors of LCD and DCD pathways could inhibit the accumulation of $\mathrm{H}_{2} \mathrm{~S}$. Therefore, we conclude that $V v L C D$ and $V v D C D$ genes contribute to the major production of $\mathrm{H}_{2} \mathrm{~S}$ in grape at low temperature.

To confirm the functions of $\mathrm{H}_{2} \mathrm{~S}$ in grape response to chilling stress, we analyzed superoxide anion radical content, MDA
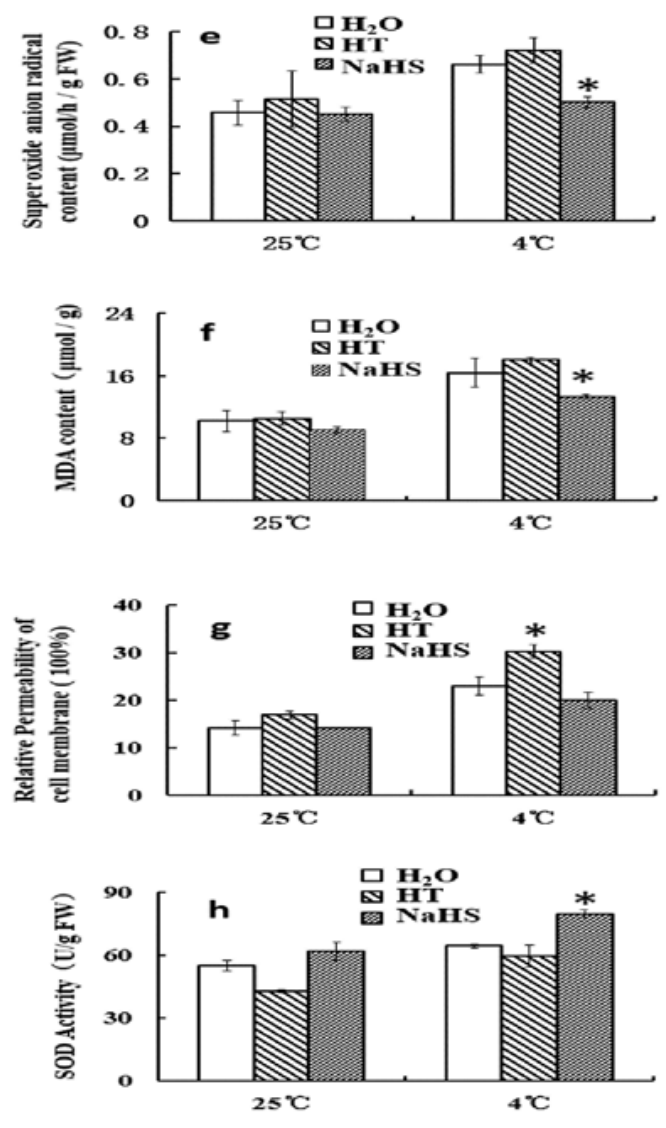

Fig. 5 Effects of low temperature and $\mathrm{H}_{2} \mathrm{~S}$ on several parameters involved in cold tolerance in V. vinifera L. 'F-242'. The values represent the average of three independent samples. a Effect of low temperature on superoxide anion radical content. $\mathbf{b}$ Effect of low temperature on MDA content. $\mathbf{c}$ Effect of temperature on the relative permeability of cell membrane. $\mathbf{d}$ Effect of low temperature on SOD activity. $\mathbf{e}$ Effect of NaHS and HT on superoxide anion radical content. $\mathbf{f}$ Effect of NaHS and HT on MDA content. $\mathbf{g}$ Effect of NaHS and HT on the relative permeability of cell membrane. $\mathbf{h}$ Effect of NaHS and HT on SOD activity. Error bars indicate $\pm S E .{ }^{*}$ indicates significant differences at $P<0.05$ (Student's $t$-test). 

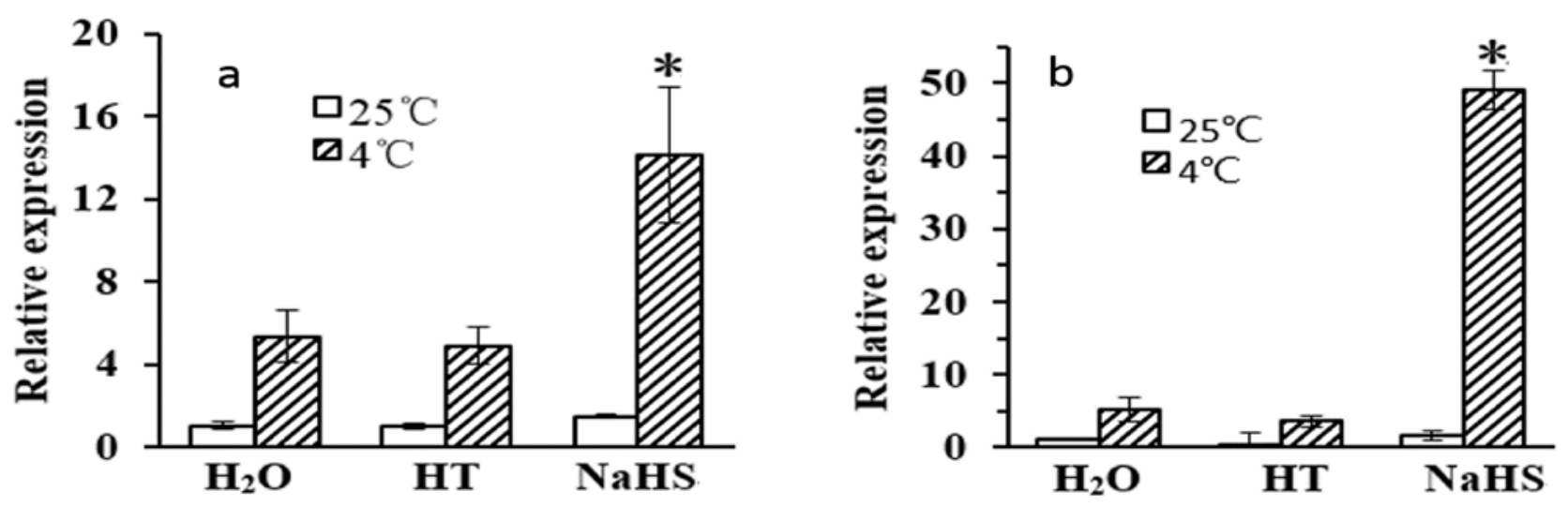

Fig. 6 Effects of HT and NaHS on VvICE1 (a) and $V v C B F 3(\mathbf{b})$ expression patterns under chilling stress in $V$. vinifera L. 'F-242'. The relative expression of $V v I C E 1$ and $V v C B F 3$ was quantified in comparison with the VvACTIN using quantitative RT-PCR with gene-specific primers (see "Material and methods"). The values represent the average of three independent samples. Error bars indicate $\pm S E$. ${ }^{*}$ indicates significant differences at $P<0.05$ (Student's $t$-test).

content, the relative permeability of the plasma membranes and SOD activity in NaHS- and HT- pretreated grape seedlings under low temperature. The results demonstrated that $\mathrm{H}_{2} \mathrm{~S}$ participated in the response of grape to chilling by protecting membrane integrity and enhancing SOD activities related to cold resistance. Meanwhile, the study of Li et al. shows that spraying NaHS improves heat tolerance in maize by alleviating the increase of electrolyte leakage and MDA [39]. In addition, Zhang and his colleagues indicate that spraying NaHS delays excessive accumulation of MDA and reactive oxygen species, but enhance SOD activity against cooper stress and droughtinduced oxidative stress in wheat seeds and soybean seedlings $[11,15]$. All these findings suggest that $\mathrm{H}_{2} \mathrm{~S}$ possibly use the similar mechanism to resist various stresses in different plants.

Transcription factors play important roles in chilling stress response in plants. For instance, the expression levels of ICE1 and $C B F 3$ can be enhanced in different freezing temperatures [40]. Ectopically expression of AtCBFs and AtICE1 in different plant species can enhance chilling tolerance [41,42], and ectopically expression of $C B F s$ from other plants is able to enhance the freezing tolerance of transgenic Arabidopsis [20,43]. In the present work, it is shown that the transcription levels of VvICE1 and $V v C B F 3$ were induced greatly and reached their peak at $7 \mathrm{~h}$ and $3 \mathrm{~d}$, respectively, under low temperature in ' $\mathrm{F}-242$ ' (data not shown). In addition, NaHS significantly induced VvICE1 and $V v C B F 3$ at low temperature. It indicates that $\mathrm{H}_{2} \mathrm{~S}$ is involved in grapevine chilling stress response by modulating $V v I C E 1$ and $V v C B F 3$ transcription. Recently, it is shown that $D R E B 1 / C B F 3$ and RD29A (also known as COR78 or LTI78, a target gene of $C B F 3$ ) can be induced by both cold and drought in plants [44-46]. In addition, $\mathrm{H}_{2} \mathrm{~S}$ up-regulates the expression of $R D 29 \mathrm{~A}$ to improve drought resistance in Arabidopsis [13]. We guess from these results that, in plants, the genes regulated by $\mathrm{H}_{2} \mathrm{~S}$ could participate not only in drought stress but also in cold stress.

To further investigate the physiological function and regulatory mechanism of $\mathrm{H}_{2} \mathrm{~S}$ in response to low temperature, some work could be conducted, such as grape genetic transformation, RNAi technology to generate the $V v L-C D$ and $V v D-C D$ mutants and transgenic grape plants for the genetic controls of $\mathrm{H}_{2} \mathrm{~S}$ responses to low temperature in the future studies.

\section{Acknowledgments}

We thank Professor Jiang Lu (China Agriculture University), Doctor Jiao Wu (China Agriculture University), Huimin Man (The Conagen Inc, USA) and Professor Chunhai Dong (Qingdao Agriculture University) for helpful suggestions, critical reading, and polishing of the manuscript. This work was supported by the National Science Foundation of Qing Dao [10-3-4-5-5-jch and 12-1-4-5-(12)-jch].

\section{Authors' contributions}

The following declarations about authors' contributions to the research have been made: conceived and designed the study: PF, XL; performed the experiments: PF, WW; analyzed the experimental data: PF, XL, WW, LH; wrote the paper: PF, WW; reviewed and edited the manuscript: PF, XL.

\section{References}

1. Wang R. Two's company, three's a crowd: can $\mathrm{H}_{2} \mathrm{~S}$ be the third endogenous gaseous transmitter? FASEB J. 2002;16(13):1792-1798. http://dx.doi. org/10.1096/fj.02-0211hyp

2. Papenbrock J, Riemenschneider A, Kamp A, Schulz-Vogt HN, Schmidt A. Characterization of cysteine-degrading and $\mathrm{H}_{2} \mathrm{~S}$-releasing enzymes of higher plants - from the field to the test tube and back. Plant Biol. 2007;9(5):582-588. http://dx.doi.org/10.1055/s-2007-965424

3. Riemenschneider A, Nikiforova V, Hoefgen R, De Kok LJ, Papenbrock J. Impact of elevated $\mathrm{H}_{2} \mathrm{~S}$ on metabolite levels, activity of enzymes and expression of genes involved in cysteine metabolism. Plant Physiol Biochem. 2005;43(5):473-483. http://dx.doi.org/10.1016/j.plaphy.2005.04.001

4. Álvarez C, Calo L, Romero LC, García I, Gotor C. An O-acetylserine(thiol) lyase homolog with L-cysteine desulfhydrase activity regulates cysteine homeostasis in Arabidopsis. Plant Physiol. 2010;152(2):656-669. http:// dx.doi.org/10.1104/pp.109.147975

5. Thomas M, Scott N. Microsatellite repeats in grapevine reveal DNA polymorphisms when analysed as sequence-tagged sites (STSs). Theor Appl Genet. 1993;86(8):985-990. 
6. Wang Y, Li L, Cui W, Xu S, Shen W, Wang R. Hydrogen sulfide enhances alfalfa (Medicago sativa) tolerance against salinity during seed germination by nitric oxide pathway. Plant Soil. 2012;351(1-2):107-119. http://dx.doi. org/10.1007/s11104-011-0936-2

7. Li ZG, Gong M, Xie H, Yang L, Li J. Hydrogen sulfide donor sodium hydrosulfide-induced heat tolerance in tobacco (Nicotiana tabacum L.) suspension cultured cells and involvement of $\mathrm{Ca}^{2+}$ and calmodulin. Plant Sci. 2012;185-186:185-189. http://dx.doi.org/10.1016/j.plantsci.2011.10.006

8. Li L, Wang Y, Shen W. Roles of hydrogen sulfide and nitric oxide in the alleviation of cadmium-induced oxidative damage in alfalfa seedling roots. BioMetals. 2012;25(3):617-631. http://dx.doi.org/10.1007/s10534-012-9551-9

9. Wang BL, Shi L, Li YX, Zhang WH. Boron toxicity is alleviated by hydrogen sulfide in cucumber (Cucumis sativus L.) seedlings. Planta. 2010;231(6):1301-1309. http://dx.doi.org/10.1007/s00425-010-1134-9

10. Zhang H, Tan ZQ, Hu LY, Wang SH, Luo JP, Jones RL. Hydrogen sulfide alleviates aluminum toxicity in germinating wheat seedlings. J Integr Plant Biol. 2010;52(6):556-567. http://dx.doi.org/10.1111/j.1744-7909.2010.00946.x

11. Zhang H, Jiao H, Jiang CX, Wang SH, Wei ZJ, Luo JP, et al. Hydrogen sulfide protects soybean seedlings against drought-induced oxidative stress. Acta Physiol Plant. 2010;32(5):849-857. http://dx.doi.org/10.1007/ s11738-010-0469-y

12. Jin Z, Xue S, Luo Y, Tian B, Fang H, Li H, et al. Hydrogen sulfide interacting with abscisic acid in stomatal regulation responses to drought stress in Arabidopsis. Plant Physiol Biochem. 2013;62:41-46. http://dx.doi. org/10.1016/j.plaphy.2012.10.017

13. Jin Z, Shen J, Qiao Z, Yang G, Wang R, Pei Y. Hydrogen sulfide improves drought resistance in Arabidopsis thaliana. Biochem Biophys Res Commun. 2011;414(3):481-486. http://dx.doi.org/10.1016/j.bbrc.2011.09.090

14. Tan JF, Zhao HJ, Hong JP, Han YL, Li H, Zhao WC. Effects of exogenous nitric oxide on photosynthesis, antioxidant capacity and proline accumulation in wheat seedlings subjected to osmotic stress. World J Agric Sci. 2008;4:307-313.

15. Zhang H, Hu LY, Hu KD, He YD, Wang SH, Luo JP. Hydrogen sulfide promotes wheat seed germination and alleviates oxidative damage against copper stress. J Integr Plant Biol. 2008;50(12):1518-1529. http://dx.doi. org/10.1111/j.1744-7909.2008.00769.x

16. Hu KD, Hu LY, Li YH, Zhang FQ, Zhang H. Protective roles of nitric oxide on germination and antioxidant metabolism in wheat seeds under copper stress. Plant Growth Regul. 2007;53(3):173-183. http://dx.doi.org/10.1007/ s10725-007-9216-9

17. Cantrel C, Vazquez T, Puyaubert J, Rezé N, Lesch M, Kaiser WM, et al. Nitric oxide participates in cold-responsive phosphosphingolipid formation and gene expression in Arabidopsis thaliana. New Phytol. 2011;189(2):415-427. http://dx.doi.org/10.1111/j.1469-8137.2010.03500.x

18. Zhao R, Sheng J, Lv S, Zheng Y, Zhang J, Yu M, et al. Nitric oxide participates in the regulation of $L e C B F 1$ gene expression and improves cold tolerance in harvested tomato fruit. Postharvest Biol Technol. 2011;62(2):121-126. http://dx.doi.org/10.1016/j.postharvbio.2011.05.013

19. Mikkelsen MD, Thomashow MF. A role for circadian evening elements in cold-regulated gene expression in Arabidopsis. Plant J. 2009;60(2):328-339. http://dx.doi.org/10.1111/j.1365-313X.2009.03957.x

20. Yamaguchi-Shinozaki K, Shinozaki K. Transcriptional regulatory networks in cellular responses and tolerance to dehydration and cold stresses. Annu Rev Plant Biol. 2006;57(1):781-803. http://dx.doi.org/10.1146/annurev. arplant.57.032905.105444

21. Knight H, Zarka DG, Okamoto H, Thomashow MF, Knight MR. Abscisic acid induces $C B F$ gene transcription and subsequent induction of cold-regulated genes via the CRT promoter element. Plant Physiol. 2004;135(3):1710-1717. http://dx.doi.org/10.1104/pp.104.043562

22. Chen L, Zhong H, Ren F, Guo QQ, Hu XP, Li XB. A novel cold-regulated gene, COR25, of Brassica napus is involved in plant response and tolerance to cold stress. Plant Cell Rep. 2011;30(4):463-471. http://dx.doi. org/10.1007/s00299-010-0952-3
23. Zhou M, Wu L, Liang J, Shen C, Lin J. Expression analysis and functional characterization of a novel cold-responsive gene CbCOR15a from Capsella bursa-pastoris. Mol Biol Rep. 2012;39(5):5169-5179. http://dx.doi. org/10.1007/s11033-011-1313-1

24. Shi Y, Tian S, Hou L, Huang X, Zhang X, Guo H, et al. Ethylene signaling negatively regulates freezing tolerance by repressing expression of $C B F$ and type-A ARR genes in Arabidopsis. Plant Cell. 2012;24(6):2578-2595. http://dx.doi.org/10.1105/tpc.112.098640

25. Sangwan V, Foulds I, Singh J, Dhindsa RS. Cold-activation of Brassica napus BN115 promoter is mediated by structural changes in membranes and cytoskeleton, and requires $\mathrm{Ca}^{2+}$ influx. Plant J. 2001;27(1):1-12. http:// dx.doi.org/10.1046/j.1365-313x.2001.01052.x

26. Ma YY, Zhang YL, Shao H, Lu J. Differential physio-biochemical responses to cold stress of cold-tolerant and non-tolerant grapes (Vitis L.) from China. J Agron Crop Sci. 2010;196(3):212-219. http://dx.doi. org/10.1111/j.1439-037X.2009.00405.X

27. Liu J, Hou L, Liu GH, Liu X, Wang XC. Hydrogen sulfide induced by nitric oxide mediates ethylene-induced stomatal closure of Arabidopsis thaliana. Chin Sci Bull. 2011;56(33):3547-3553. http://dx.doi.org/10.1007/ s11434-011-4819-y

28. Zhao HJ, Zou Q. Protective effects of exogenous antioxidants and phenolic compounds on photosynthesis of wheat leaves under high irradiance and oxidative stress. Photosynthetica. 2002;40(4):523-527. http://dx.doi. org/10.1023/A:1024339716382

29. Ederli L, Pasqualini S, Batini P, Antonielli M. Photoinhibition and oxidative stress: effects on xanthophyll cycle, scavenger enzymes and abscisic acid content in tobacco plants. J Plant Physiol. 1997;151(4):422-428. http:// dx.doi.org/10.1016/S0176-1617(97)80006-5

30. Hodges DM, DeLong JM, Forney CF, Prange RK. Improving the thiobarbituric acid-reactive-substances assay for estimating lipid peroxidation in plant tissues containing anthocyanin and other interfering compounds. Planta. 1999;207(4):604-611. http://dx.doi.org/10.1007/s004250050524

31. Welti R, Li W, Li M, Sang Y, Biesiada H, Zhou HE, et al. Profiling membrane lipids in plant stress responses. J Biol Chem. 2002;277(35):31994-32002. http://dx.doi.org/10.1074/jbc.M205375200

32. Donahue JL, Okpodu CM, Cramer CL, Grabau EA, Alscher RG. Responses of antioxidants to paraquat in pea leaves (relationships to resistance). Plant Physiol. 1997;113(1):249-257. http://dx.doi.org/10.1104/pp.113.1.249

33. Iandolino AB, da Silva FG, Lim H, Choi H, Williams LE, Cook DR. High-quality RNA, cDNA, and derived EST libraries from grapevine (Vitis vinifera L.). Plant Mol Biol Rep. 2004;22(3):269-278. http://dx.doi. org/10.1007/BF02773137

34. Li L, Rose P, Moore PK. Hydrogen sulfide and cell signaling. Annu Rev Pharmacol Toxicol. 2011;51(1):169-187. http://dx.doi.org/10.1146/ annurev-pharmtox-010510-100505

35. Wang R. Physiological implications of hydrogen sulfide: a whiff exploration that blossomed. Physiol Rev. 2012;92(2):791-896. http://dx.doi.org/10.1152/ physrev.00017.2011

36. Riemenschneider A, Wegele R, Schmidt A, Papenbrock J. Isolation and characterization of a D-cysteine desulfhydrase protein from Arabidopsis thaliana. FEBS J. 2005;272(5):1291-1304. http://dx.doi. org/10.1111/j.1742-4658.2005.04567.x

37. Soutourina J, Blanquet S, Plateau P. Role of D-cysteine desulfhydrase in the adaptation of Escherichia coli to D-cysteine. J Biol Chem. 2001;276(44):40864-40872. http://dx.doi.org/10.1074/jbc.M102375200

38. Riemenschneider A. Isolation and characterization of cysteine-degrading and $\mathrm{H}_{2} \mathrm{~S}$-releasing proteins in higher plants [PhD thesis]. Hannover: Leibniz Universität Hannover; 2006.

39. Li ZG, Ding XJ, Du PF. Hydrogen sulfide donor sodium hydrosulfideimproved heat tolerance in maize and involvement of proline. J Plant Physiol. 2013;170(8):741-747. http://dx.doi.org/10.1016/j.jplph.2012.12.018

40. Miura K, Jin JB, Lee J, Yoo CY, Stirm V, Miura T, et al. SIZ1-mediated sumoylation of ICE1 controls CBF3/DREB1A expression and freezing 
tolerance in Arabidopsis. Plant Cell. 2007;19(4):1403-1414. http://dx.doi. org/10.1105/tpc.106.048397

41. Xiang DJ, Hu XY, Zhang Y, Yin KD. Over-expression of ICE1 gene in transgenic rice improves cold tolerance. Rice Sci. 2008;15(3):173-178. http://dx.doi.org/10.1016/S1672-6308(08)60039-6

42. Gilmour SJ, Sebolt AM, Salazar MP, Everard JD, Thomashow MF. Overexpression of the Arabidopsis CBF3 transcriptional activator mimics multiple biochemical changes associated with cold acclimation. Plant Physiol. 2000;124(4):1854-1865. http://dx.doi.org/10.1104/pp.124.4.1854

43. Chinnusamy V, Zhu J, Zhu JK. Gene regulation during cold acclimation in plants. Physiol Plant. 2006;126(1):52-61. http://dx.doi. org/10.1111/j.1399-3054.2006.00596.x

44. Dubouzet JG, Sakuma Y, Ito Y, Kasuga M, Dubouzet EG, Miura S, et al. OSDREB genes in rice, Oryza sativa L., encode transcription activators that function in drought-, high-salt- and cold-responsive gene expression. Plant J. 2003;33(4):751-763. http://dx.doi.org/10.1046/j.1365-313X.2003.01661.x

45. Zhao J, Ren W, Zhi D, Wang L, Xia G. Arabidopsis DREB1A/CBF3 bestowed transgenic tall fescue increased tolerance to drought stress. Plant Cell Rep. 2007;26(9):1521-1528. http://dx.doi.org/10.1007/s00299-007-0362-3

46. Shinozaki K, Yamaguchi-Shinozaki K. Molecular responses to drought and cold stress. Curr Opin Biotechnol. 1996;7(2):161-167. http://dx.doi. org/10.1016/S0958-1669(96)80007-3 